\title{
EVALUASI KELAYAKAN EKONOMI PROYEK PEMBANGUNAN JALAN TOL TRANS SUMATERA RUAS BAKAUHENI - TERBANGGI BESAR MELALUI COST BENEFIT ANALYSIS
}

\section{EVALUATION OF ECONOMIC FEASIBILITY OF TRANS SUMATERA TOLL ROAD DEVELOPMENT (BAKAUHENI - TERBANGGI BESAR) THROUGH COST BENEFIT ANALYSIS}

\author{
Windy Mitasari*, Doddy Aditya Iskandar** \\ *Mahasiswa Magister Perencanaan Wilayah dan Kota, Universitas Gajah Mada \\ Email: mitasariwindy@gmail.com \\ ** Dosen Magister Perencanaan Wilayah dan Kota, Universitas Gajah Mada
}

Diterima: 14 Desember 2020; Direvisi: 29 Desember 2020; Disetujui: 30 Desember 2020

\begin{abstract}
ABSTRAK
Proyek Jalan Tol Trans Sumatera ruas Bakauheni - Terbanggi Besar merupakan proyek yang tidak layak secara finansial namun layak secara ekonomi. Proyek Jalan Tol Trans Sumatera di ruas Bakahueni - Terbanggi Besar resmi dimulai pembangunannya pada tanggal 30 April 2015 dan telah diresmikan penggunaannya secara penuh pada tanggal 8 Maret 2019. Proyek ini memiliki asumsi Internal Rate of Return 11,80\% dengan struktur pemodalan dan komposisi pinjaman dan ekuitas sebesar 48\%:52\%, termasuk porsi ekuitas proyek ini diperoleh dari Penyertaan Modal Negara dan porsi pinjaman dijamin oleh Pemerintah. Penelitian dilakukan dengan metode perbandingan manfaat dengan biaya (Benefit Cost Ratio) dan bertujuan melakukan evaluasi kelayakan ekonomi proyek Bakauheni - Terbanggi Besar. Biaya yang digunakan adalah biaya proyek dan biaya lingkungan sebagai bentuk eksternalitas negatif proyek ini sedangkan manfaat yang dihitung berdasarkan manfaat yang diperoleh pengguna jalan tol tersebut. Biaya total dari proyek ini adalah $\mathrm{Rp}$ 27,93 Triliun dan manfaat nya sebesar Rp. 31,43 Triliun sehingga BCR sebesar 1,13. Dilihat dari nilai BCR, Proyek ini merupakan proyek yang layak secara ekonomi..
\end{abstract}

Kata kunci: Evaluasi, Infrastruktur, Jalan Tol Trans Sumatera, Ekonomi, Kelayakan

\begin{abstract}
The Trans Sumatra Toll Road Project for the Bakauheni - Terbanggi Besar section is a project that is not financially feasible but economically feasible. The Trans Sumatra Toll Road Project in the Bakahueni - Terbanggi Besar section officially began construction on April 30, 2015 and was fully inaugurated on March 8, 2019. This project assumes an Internal Rate of Return 11.80\% with a capital structure and loan composition and 48\%: 52\% equity, including the portion of the project equity obtained from the State Equity Participation and the portion of the loan guaranteed by the Government. The research was conducted using the Benefit Cost Ratio method and aims to evaluate the economic feasibility of the Bakauheni - Terbanggi Besar project. The costs used are project costs and environmental costs as a form of negative externalities of this project, while the benefits are calculated based on the benefits obtained by the toll road users. The total cost of this project is IDR 27.93 trillion and the benefits are IDR. 31.43 trillion so that the BCR is 1.13. Judging from the BCR value, this project is an economically viable project.
\end{abstract}

Keywords: Evaluation, Infrastructure, Trans Sumatra Toll Road, Economy, Feasibility 


\section{PENDAHULUAN}

Sumatera merupakan pulau yang memiliki kontribusi ekonomi terbesar kedua untuk Indonesia setelah pulau Jawa (BPS 2019). Oleh karena itu pemerintah perlu mengembangkan perekonomian di pulau Sumatera sehingga dapat menjadi lokomotif keberlanjutan dan penyokong perekonomian di Indonesia. Lalu lintas logistik di Pulau Sumatera saat ini sebagian besar dilakukan melalui jalur darat yaitu jalur lintas Sumatera (non-tol) yang terbagi menjadi lintas barat dan lintas timur dalam distribusi orang dan barang. Oleh karenanya, dalam rangka meningkatkan kelancaran lalu lintas logistik dan distribusi di pulau Sumatera, pemerintah berupaya meningkatkan konektivitas pulau Sumatera melalui pembangunan infrastruktur Jalan Tol Trans Sumatera (JTTS).

JTTS merupakan jaringan jalan tol sepanjang kurang lebih $2.700 \mathrm{~km}$, terbagi menjadi 24 ruas, akan menghubungkan pulau Sumatera dari Banda Aceh hingga Bakauheni, Lampung. Proyek ini memiliki ruas prioritas yang beberapa diantaranya telah beroperasi dan salah satunya adalah ruas Bakauheni-Terbanggi Besar dengan bentangan sepanjang 140,94 km dan terbagi atas 3 seksi.

Proyek Jalan Tol Trans Sumatera yang ditugaskan merupakan proyek yang tidak layak secara finansial namun layak secara ekonomi. Proyek Jalan Tol Trans Sumatera di ruas Bakahueni - Terbanggi Besar ini resmi dimulai pembangunannya pada tanggal 30 April 2015 dan telah diresmikan penggunaannya secara penuh pada tanggal 8 Maret 2019. Proyek ini memiliki asumsi Internal Rate of Return $11,80 \%$ dengan struktur pemodalan dengan komposisi pinjaman dan ekuitas sebesar 48\% : 52\%, di mana porsi ekuitas proyek ini diperoleh dari Penyertaan Modal Negara dan porsi pinjaman dijamin oleh Pemerintah.

Dalam rangka melakukan evaluasi atas proyek dimaksud, perlu dilakukan analisis manfaat dan biaya proyek Bakauheni - Terbanggi Besar dalam rangka mengevaluasi kelayakan ekonomi proyek JTTS tersebut. Analisis manfaat dan biaya ini dilakukan untuk menghitung besarnya manfaat serta biaya yang ditimbulkan dari adanya proyek. Metode yang digunakan adalah metode perbandingan manfaat dan biaya (Benefit Cost Ratio). Biaya yang digunakan adalah biaya proyek dan biaya lingkungan sebagai bentuk eksternalitas negatif proyek ini sedangkan manfaat yang dihitung berdasarkan manfaat yang diperoleh pengguna jalan tol tersebut.

Penelitian yang pernah dilakukan sebelumnya untuk proyek Public Private Partnership di Africa oleh Matanhire (2019) dan proyek jalan tol Trans Sumatera Ruas Palembang Indralaya oleh Diez (2015) dilakukan dengan metode Cost and benefit Analysis (CBA). Perbedaanya selain lokasi yang berbeda dengan peneliti sebelumnya juga terletak pada identifikasi biaya ekternalitas yang meliputi biaya alih fungsi lahan dan biaya polusi serta dikarenakan penelitian ini merupakan penelitian evaluasi sehingga prediksi traffic yang digunakan memakai prediksi traffic dengan dasar saat proyek telah beroperasi.

Penelitian ini perlu dilakukan mengingat pentingnya pengambilan keputusan kebijakan Pemerintah yang didasari dari kajian yang lengkap. Selain itu pula penelitian untuk proyek penugasan Pemerintah kepada Badan Usaha Milik Negara (BUMN) yang sudah beroperasi masih minim dilakukan hal ini disebabkan karena skema proyek penugasan tergolong baru dilakukan di Indonesia. Sehingga hal ini perlu dilakukan sebagai acuan bagaimana Pemerintah menentukan kebijakan untuk proyek sejenis.

\section{METODE}

Metode analisis yang dipakai dalam penelitian ini adalah analisis Biaya dan Manfaat/ Cost and benefit Analysis (CBA). CBA digunakan untuk menjelaskan hasil perkiraan seluruh biaya dan manfaat yang diperoleh dari proyek dengan tujuan untuk menghitung nilai ekonomi bersih saat ini. Identifikasi biaya ekonomi yaitu biaya langsung dan biaya tidak langsung serta 
identifikasi manfaat ekonomi melalui manfaat penghematan Biaya Operasional Kendaraan dan manfaat penghematan waktu.

Data yang digunakan dalam jurnal ini adalah data primer dan data sekunder. Data primer yaitu data yang diperoleh melalui wawancara mendalam terhadap narasumber seperti Kementerian Keuangan, BPJT, dan PT Hutama Karya (Persero) sedangkan data sekunder diperoleh dari data proyek dari PT Hutama Karya dan data dari penelitian lain.

Setelah melakukan identifikasi biaya dan manfaat kemudian dilanjutkan analisis dengan metode BCR. Metode ini membandingkan antara total manfaat yang telah diidentifikasi selama umur investasi yang direncanakan yaitu selama 40 tahun dan total biaya yang semuanya dinyatakan dalam tahun ke-0 (present worth). Manfaat dan biaya yang diidentifikasi berdasarkan proyeksi setelah proyek beroperasi.

\section{HASIL DAN PEMBAHASAN}

Guna menjawab pertanyaan dalam penelitian ini, salah satu analisis yang digunakan ialah analisis Biaya dan Manfaat/ Cost and benefit Analysis (CBA). CBA digunakan untuk menjelaskan hasil perkiraan seluruh biaya dan manfaat yang diperoleh dari proyek dengan menghitung nilai ekonomi bersih saat ini yang diharapkan unutk perkembangan perekonomian Indonesia dan wilayah Propinsi Lampung pada khususnya.

Pada CBA, perhitungan yang dilakukan terbatas pada penambahan/pengurangan biaya dan manfaat (manfaat bersih) secara langsung sepanjang umur ekonomis proyek. Hal ini dapat dicapai dengan membandingkan skenario 'dengan Proyek' dan skenario 'tanpa Proyek' dalam aspek kegiatan ekonomi. Sedangkan lingkup CBA mencakup seluruh pengeluaran biaya (investasi) proyek dan manfaat ekonomi bersih, tanpa mempertimbangkan pihak yang memiliki, mengoperasikan, atau membiayainya, termasuk adanya dukungan pemerintah tidak diperhitungkan dalam perhitungan biaya.

Hal ini karena dalam analisis ini pembayaran pajak merupakan transfer pendapatan dari masyarakat/entitas kepada pemerintah, yang kemudian dapat digunakan untuk kepentingan fiskal. Dalam konteks ini, keuntungan yang didapat oleh pemerintah merupakan kerugian bagi individu yang membayar pajak. Maka dalam analisis ekonomi, pembayaran pajak tidak dianggap sebagai komponen biaya, dan pada umumnya tidak diikutsertakan dalam perhitungan CBA. Komponen lainnya misalnya, biaya tanah, subsidi, Viability Gap Fund (VGF), atau dana hibah dari pemerintah juga merupakan pembayaran transfer langsung, namun dengan arah yang berlawanan dengan pajak. Oleh sebab itu, dukungan dari pemerintah harus dikeluarkan dari komponen manfaat maupun biaya.

\section{Estimasi Faktor Konversi Standar/Standard Conversion Facto (SCF)}

Berdasarkan Peraturan Menteri Bappenas No 4 Tahun 2015 tentang Tata Cara Pelaksanaan Kerjasama Pemerintah dan Badan Usaha, penetapan biaya ekonomi diperkirakan dengan cara mengkonversi harga pasar menjadi harga ekonomi untuk setiap input dan hasil berdasarkan faktor konversi yang sesuai. Apabila harga pasar tidak dapat mencerminkan biaya peluang (opportunity cost), maka yang dihitung atau digunakan adalah harga ekonomi (harga bayangan/shadow price), bukan harga pasar (sebagaimana digunakan dalam analisis keuangan).

Dalam menghitung biaya ekonomi, barang-barang yang tidak diperdagangkan perlu dikonversi menjadi harga ekonomi yang mencerminkan biaya peluang. Hal ini dilakukan dengan menggunakan Standard Conversion Factor/SCF. Shadow price dapat diperkirakan berdasarkan harga di pasar dunia yang mencerminkan peluang-peluang perdagangan aktual dari negara yang bersangkutan. Perkiraan nilai SCF dibuat berdasarkan nilai ekspor dan impor. SCF dihitung dengan menggunakan rumus berikut ini: 


$$
\mathrm{SCF}=\frac{(M+X)}{[(M+T m)+(X-T x)]}
$$

Dimana:

$\mathrm{M}=$ Nilai biaya, asuransi dan muatan tonase (cost, Insurance and Freight/"CIF") dari total impor

$\mathrm{X}=$ Free on Board ("FOB") dari total ekspor

$\mathrm{Tm}=$ Pajak Impor

Tx $=$ Pajak ekspor

Berdasarkan data ekspor dan impor dalam Laporan Keuangan Pemerintah Pusat Tahun 2019, SCF diperkirakan sebesar 0,99. Terkait dengan konversi ke harga ekonomi yang digunakan dalam CBA, barang-barang yang diperdagangkan cukup disesuaikan dengan pajak terkait yang dibayarkan.

Tabel 1. Perhitungan Standard Conversion Factor

\begin{tabular}{clr}
\hline No & \multicolumn{1}{c}{ Tahun } & \multicolumn{1}{c}{2019} \\
\hline 1 & Export Value (Triliun Rp) & 2369,455 \\
2 & Import Value (Triliun Rp) & 2415,14658 \\
3 & Export duties (Triliun Rp) & 3,432 \\
4 & Import duties (Triliun Rp) & 37,56 \\
5 & $(5)=(1)+(2)$ & 4784,60158 \\
6 & $(6)=(5)-(3)+(4)$ & 4.819 \\
7 & $\mathrm{SCF}=(5) /(6)$ & 0,99 \\
\hline \multicolumn{2}{l}{ Sumber: Laporan Keuangan Pemerintah Pusat 2019, diolah }
\end{tabular}

Untuk barang-barang dimana Indonesia adalah importir bersih, biaya peluang penggunaan satu unit tambahan bukan merupakan harga finansial (setelah pajak impor), tetapi harga sebelum pajak impor (karena pajak impor merupakan transfer kepada pemerintah). Hal ini merupakan harga CIF. Pajak impor diperkirakan sebesar 11\%, sehingga faktor penyesuaian ditetapkan sebesar 0,90. Sehingga faktor konversi dapat dibagi menjadi 4 bagian yaitu (a) tradable bernilai 1,00, (b) non-tradable bernilai 0,99, (c) skilled labor bernilai 1,00 dan (d) unskilled labor bernilai 0,90.

\section{Identifikasi dan Perhitungan Biaya Ekonomi Proyek}

Biaya ekonomi berbeda dengan biaya keuangan, karena biaya ekonomi ditentukan oleh biaya peluang dari penggunaan sumber daya seperti modal, tenaga kerja, atau lahan (bukan harga transaksi atau harga pasar). Dalam CBA, biaya-biaya ekonomi yang berkaitan dengan proyek dalam skenario 'dengan proyek' dapat dibedakan ke dalam dua kategori:

\section{a. Biaya-biaya langsung (biaya-biaya berwujud)}

Biaya-biaya langsung merupakan seluruh biaya keuangan selama proyek berlangsung tanpa mempertimbangkan pihak yang membiayai (masyarakat umum atau badan usaha) kecuali pajak (langsung maupun tidak langsung) dan biaya tanah karena tanah biaya tanah merupakan biaya yang dikeluarkan pemerintah.

Biaya tersebut antara lain:

1. Biaya Perencanaan terdiri dari biaya konsultan teknis, konsultan keuangan, konsultang pengadaan tanah, dan konsultan independen checker serta konsultan hukum. Biaya konsultan teknis dibagi menjadi 2 (dua) yaitu Rencana Teknik Akhir (DED) dan Studi Kelayakan serta Business Plan, sedangkan konsultan hukum pada masa penugasan dan masa konstruksi. untuk konsultan independent checker 
digunakan sebagai partner BUJT untuk memeriksa hasil pekerjaan dari konsultan teknis dan konsultan keuangan.

2. Biaya Konstruksi untuk pembangunan Jalan Tol Bakauheni terbanggi Besar mencakup 3 seksi, total panjang jalan yaitu 140,94 km

3. Biaya Peralatan Tol terdiri dari sistem pengumpulan tol dan biaya peralatan untuk manajemen lalu lintas serta sistem informasi dan komunikasi jalan tol.

4. Biaya supervisi terdiri dari biaya langsung personil dan biaya langsung non personil untuk pelaksanaan pengawasan dan pemeriksaan pekerjaan konstruksi serta Pengendali Mutu Independen (PMI).

5. Biaya eskalasi dipengaruhi oleh faktor inflasi akibat perbedaan waktu pada saat perhitungan dengan masa pelaksanaan.

6. Biaya overhead adalah biaya-biaya yang dikeluarkan pada masa persiapan awal sampai dengan selesainya pelaksanaan konstruksi antara lain biaya operasional, seperti biaya gaji dan tunjangan, administrasi, peralatan kantor, biaya pengadaan kenadaraan, dan lainnya.

7. Biaya operasional dan pemeliharaan yang dikeluarkan PT Hutama Karya dalam rangka mengelola dan merawat jalan tol Bakauheni Terbanggi Besar.

Total perkiraan biaya langsung selama 40 tahun secara kotor adalah Rp 15,15 Triliun selama 40 tahun jangka waktu Perjanjian Kerja Sama. Rincian biaya langsung ditunjukkan dalam tabel berikut:

Tabel 2. Rincian Biaya langsung Proyek Bakauheni Terbanggi Besar

\begin{tabular}{|c|c|c|c|c|}
\hline \multicolumn{5}{|c|}{ Biaya Modal } \\
\hline Capital Expenditure & \multicolumn{2}{|r|}{ Biaya Finansial } & \multicolumn{2}{|r|}{ Biaya ekonomi } \\
\hline Tanah & - & & - & \\
\hline Desain (FED) & $\mathrm{Rp}$ & 61.101 Juta & $\mathrm{Rp}$ & 54.991 Juta \\
\hline Konstruksi & $\mathrm{Rp}$ & 12.220.203 Juta & Rp & 10.998.183 Juta \\
\hline Peralatan Tol & $\mathrm{Rp}$ & 244.404 Juta & $\mathrm{Rp}$ & 219.964 Juta \\
\hline Supervisi & $\mathrm{Rp}$ & 183.303 Juta & $\mathrm{Rp}$ & 164.973 Juta \\
\hline Eskalasi & $\mathrm{Rp}$ & 1.019 .080 Juta & Rp & 917.172 Juta \\
\hline Overhead & $\mathrm{Rp}$ & 305.505 Juta & Rp & 274.955 Juta \\
\hline PPN $10 \%$ & $\mathrm{Rp}$ & 1.372.809 Juta & - & \\
\hline Financial Cost & $\mathrm{Rp}$ & 185.006 Juta & - & \\
\hline IDC Sindikasi & $\mathrm{Rp}$ & 1.203.953 Juta & - & \\
\hline Total Biaya Modal & $\mathbf{R p}$ & 16.795.364 Juta & $\mathbf{R p}$ & 12.630.236 Juta \\
\hline \multicolumn{5}{|c|}{ Biaya Operasional } \\
\hline Pengumpulan Tol & Bia & a Finansial & Bia & a ekonomi \\
\hline Biaya Personil & $\mathrm{Rp}$ & 238.640 Juta & Rp & 236.253 Juta \\
\hline Biaya Non Personil & $\mathrm{Rp}$ & 76.057 Juta & $\mathrm{Rp}$ & 75.296 Juta \\
\hline Biaya Pemeliharaan/Penggantian 2 Tahunan & $\mathrm{Rp}$ & 742 Juta & Rp & 734 Juta \\
\hline Biaya Pemeliharaan/Penggantian 3 Tahunan & $\mathrm{Rp}$ & 5.033 Juta & Rp & 4.983 Juta \\
\hline Biaya Pemeliharaan/Penggantian 5 Tahunan & $\mathrm{Rp}$ & 443.438 Juta & $\mathrm{Rp}$ & 439.003 Juta \\
\hline
\end{tabular}




\begin{tabular}{|c|c|c|c|c|}
\hline \multicolumn{5}{|l|}{ Pelayanan Pemakai Jalan Tol } \\
\hline Biaya Personil & $\mathrm{Rp}$ & 199.723 Juta & $\mathrm{Rp}$ & 197.725 Juta \\
\hline Biaya Non Personil - Pengaturan Lalu Lintas & $\mathrm{Rp}$ & 366 Juta & $\mathrm{Rp}$ & 362 Juta \\
\hline Biaya Non Personil - Pelayanan Lalu Lintas & $\mathrm{Rp}$ & 131.663 Juta & $\mathrm{Rp}$ & 130.347 Juta \\
\hline Biaya Pemeliharaan/Penggantian 3 Tahunan & $\mathrm{Rp}$ & 71.290 Juta & $\mathrm{Rp}$ & 70.577 Juta \\
\hline Biaya Pemeliharaan/Penggantian 7 Tahunan & $\mathrm{Rp}$ & 25.558 Juta & $\mathrm{Rp}$ & 25.303 Juta \\
\hline \multicolumn{5}{|l|}{ Biaya Pemeliharaan } \\
\hline Pemeliharaan Rutin & $\mathrm{Rp}$ & 154.377 Juta & $\mathrm{Rp}$ & 152.833 Juta \\
\hline Pemeliharaan Berkala 2 Tahunan & $\mathrm{Rp}$ & 233.743 Juta & $\mathrm{Rp}$ & 231.405 Juta \\
\hline Pemeliharaan Berkala 3 Tahunan & $\mathrm{Rp}$ & 25.884 Juta & $\mathrm{Rp}$ & 25.625 Juta \\
\hline Pemeliharaan Berkala 4 Tahunan & $\mathrm{Rp}$ & 128.566 Juta & $\mathrm{Rp}$ & 127.280 Juta \\
\hline Pemeliharaan Berkala 5 Tahunan & $\mathrm{Rp}$ & 812.786 Juta & $\mathrm{Rp}$ & 804.658 Juta \\
\hline Biaya Administrasi dan Umum & $\mathrm{Rp}$ & 596 Juta & $\mathrm{Rp}$ & 590 Juta \\
\hline Total operasional and Pemeliharaan & $\mathbf{R p}$ & 2.548.461 Juta & Rp & 2.522.976 Juta \\
\hline Total Biaya selama 40 tahun & $\mathbf{R p}$ & 19.343.825 Juta & $\mathbf{R p}$ & 15.153.212 Juta \\
\hline
\end{tabular}

Sumber: Hasil Analisis, 2020

Total belanja modal dan operasional pada CBA berbeda dari total belanja modal dan operasional pada model keuangan karena, dalam CBA, PPN (10\%) dan biaya keuangan dikecualikan dari perhitungan biaya ekonomi.

\section{b. Biaya-biaya tidak langsung (biaya-biaya tidak berwujud)}

Biaya-biaya langsung untuk investasi dalam Proyek termasuk biaya-biaya modal dan biaya-biaya operasional yang ditanggung oleh PT Hutama Karya (HK). Sedangkan biaya-biaya tidak langsung didapatkan dari faktor-faktor eksternal seperti lingkungan hidup/sosial/ekonomi yang berkaitan dengan pembangunan proyek tol atau penggunaan sumber daya tertentu seperti alih fungsi lahan menjadi tol. Biaya tidak langsung yang dapat diidentifikasi dalam penelitian ini adalah biaya alih fungsi lahan pertanian menjadi jalan tol dan biaya polusi yang diakibatkan adanya jalan tol.

1. Biaya Alih Fungsi Lahan

Biaya alih fungsi lahan dalam penelitian ini diperhitungkan dengan kesempatan yang hilang atas lahan pertanian dan perkebunan yang ada sebelum lahan ini berubah menjadi jalan tol. Kebutuhan lahan untuk pembangunan jalan tol Bakauheni Terbanggi Besar seluas $1181 \mathrm{Ha}$ yang tersebar di 70 desa, 18 kecamatan dan 3 kabupaten. Kebutuhan pada Kabupaten Lampung Selatan yang akan terkena proyek seluas 900,5 Ha, untuk Kabupaten Pesawaran kebutuhan lahan seluas 37,79 Ha sedangkan Kabupaten Lampung Tengah kebutuhan lahan seluas 242,84 Ha. Pada umumnya lahan yang terkena berupa sawah dan kebun serta beberapa rumah. Dengan asumsi semua lahan dapat digunakan untuk pertanian dan Rata-rata pendapatan usaha tani (pendapatan atas biaya total) padi sebesar Rp10.212.647,11 (Handayani, Irwan, and Begem 2017) maka didapatkan total biaya tidak langsung dengan rincian pada tabel berikut: 
Evaluasi Kelayakan Ekonomi Proyek Pembangunan Jalan Tol Trans Sumatera Ruas Bakauheni - Terbanggi Besar Melalui Cost Benefit Analysis

Windy Mitasari, Doddy Aditya Iskandar

Tabel 3. Rincian Biaya Tidak Langsung Tol Bakauheni Terbanggi Besar

\begin{tabular}{lccc}
\hline \multicolumn{1}{c}{ Biaya Alih Fungsi Lahan } & Luasan & Biaya Finansial & Biaya Ekonomi \\
\hline Kabupaten Lampung Selatan & 900,5 & Rp9.196 Juta & Rp8.277 Juta \\
Kabupaten Pesawaran & 37,79 & Rp386 Juta & Rp347 Juta \\
Kabupaten Lampung Tengan & 242,84 & Rp2.480 Juta & Rp2.232 Juta \\
\hline Total Biaya & $\mathbf{1 1 8 1 , 1 3}$ & Rp12.062 Juta & Rp10.856 Juta \\
\hline
\end{tabular}

Sumber: Hasil Analisis, 2020

2. Biaya Polusi

Biaya polusi dalam penelitian ini diperhitungkan karena adanya polusi dari kendaraan bermotor yang melewati jalan tol setelah jalan tol beroperasi. Mengestimasi nilai kerugian ekonomi akibat emisi kendaraan umum estimasi nilai pajak emisi per zat pencemar yang dihasilkan oleh kendaraan umum berbahan bakar bensin adalah HC sebesar Rp 1,339/gram atau Rp 1.339/kg dan CO sebesar Rp 0,209/gram atau Rp 209/kg (Hidayat, Nuva, and Syafitri 2017) dengan keluaran polutan dalam satuan kendaraan menggunakan ambang batas emisi sesuai Peraturan Menteri Negara Lingkungan Hidup Republik Indonesia Nomor 10 tahun 2012 yaitu untuk kendaraan bermotor ambang batas gas buang sebesar $\mathrm{CO} 2 \mathrm{gr} / \mathrm{km}$ dan $\mathrm{HC} 0,8$ gr/km (Menteri Lingkungan Hidup 2014).

Tabel 4. Perhitungan Nilai Polutan Per Kendaraan

\begin{tabular}{cccc}
\hline Uraian & Satuan & HC & CO \\
\hline Keluaran Per Kendaraan & gram/km & 0,8 & 2 \\
Nilai Pajak Emisi & Rp/gram & 1,339 & 0,209 \\
Panjang Jalan & $\mathrm{km}$ & 140,9 & 140,9 \\
Nilai/kendaraan & $\mathrm{Rp}$ & 150,93208 & 58,8962 \\
\hline
\end{tabular}

Sumber: hasil analisis, 2020

Dengan nilai estimasi tersebut diatas, dapat diperhitungkan untuk biaya polusi pada jalan tol trans Sumatera ruas Bakauheni Terbanggi Besar yaitu sebesar Rp 23,273 Milyar selama 40 tahun (masa konsesi). Dengan perhitugan sebagai berikut:

\begin{tabular}{lccccc}
\multicolumn{7}{c}{ Tabel 5. Perhitungan biaya polusi } \\
\multicolumn{1}{c}{ Biaya Polusi } & $\mathbf{4}$ & $\mathbf{1 0}$ & $\mathbf{2 0}$ & $\mathbf{3 0}$ & $\mathbf{4 0}$ \\
& $\mathbf{2 0 1 9}$ & $\mathbf{2 0 2 5}$ & $\mathbf{2 0 3 5}$ & $\mathbf{2 0 4 5}$ & $\mathbf{2 0 5 5}$ \\
\hline Biaya/ & & & & & \\
Kendaraan & $\mathrm{Rp} \mathrm{210}$ & $\mathrm{Rp} 248$ & $\mathrm{Rp} 311$ & $\mathrm{Rp} 373$ & $\mathrm{Rp} 436$ \\
LHR & 11145 & 15394 & 25324 & 41634 & 68794 \\
Total Biaya (juta) & $\mathrm{Rp} \mathrm{854}$ & $\mathrm{Rp} 1.391$ & $\mathrm{Rp2.870}$ & $\mathrm{Rp5} .676$ & $\mathrm{Rp} 10.959$ \\
\hline
\end{tabular}

Sumber: Analisis Penulis, 2020

\section{Identifikasi dan Perhitungan Manfaat Ekonomi Proyek}

Untuk proyek transportasi seperti pembangunan maupun perbaikan jalan, manfaat atau penghematan yang diperoleh masyarakat dapat dikuantifikasikan berdasarkan perbedaan antara dengan dan tanpa proyek. Manfaat langsung yang dirasakan oleh masyarakat biasanya diambil dari selisih Biaya Operasi Kendaraan (BOK) dan selisih dari Nilai Waktu dimana masyarakat mendapatkan penghematan BOK dan Nilai Waktu jika melewati ruas jalan tol 
yang telah dipelihara oleh proyek ini. Perbedaan yang paling signifikan dan dapat dikuantifikasi adalah perbedaan kecepatan antara dengan dan tanpa proyek sehingga dalam analisis ini, BOK dan Nilai Waktu yang akan dikuantifikasi untuk dihitung nilai manfaatnya dalam rupiah.

\section{Asumsi perhitungan manfaat proyek}

Nilai waktu dengan satuan rupiah/orang/jam di dapat dari UMR masyarakat di Provinsi Lampung pada tahun 2020 yaitu sekitar Rp2.432.0001,57 per bulan dan sekitar Rp269.184.019,84 per tahun. Jam kerja rata-rata dalam setahun adalah 8 jam per hari dikalikan 22 hari kerja dalam sebulan dan dikalikan 12 bulan sehingga menghasilkan 2.112 jam per tahun. Dari hasil perhitungan sebelumnya maka nilai waktu orang per jam pada saat bekerja adalah pendapatan per bulan dibagi dengan waktu kerja per tahun sehingga didapat nilai sekitar Rp13.818,19 per jam.

Asumsi lain yang penting adalah asumsi kecepatan rata-rata, dengan rata-rata kecepatan $80 \mathrm{~km} / \mathrm{jam}$ di jalan tol karena kecepatan di jalan tol berkisar antara $60 \mathrm{~km} / \mathrm{jam}$ sampai dengan $100 \mathrm{~km} / \mathrm{jam}$. Proyeksi traffic ditetapkan berdasarkan data history traffic dalam 2 tahun terakhir sejak ruas tol beroperasi sehingga LHR ditetapkan $90 \%$ dari LHR proyeksi dalam PPJT. Asumsi selengkapnya dapat dilihat pada tabel berikut:

Tabel 6. Asumsi Ekonomi Perhitungan Manfaat Jalan tol Bakauheni Terbanggi Besar

\begin{tabular}{ll}
\hline \multicolumn{2}{c}{ Asumsi Ekonomi } \\
\hline Jumlah hari dalam satu tahun & 365 \\
Jumlah jam dalam sehari & 24 \\
Rata-Rata LHR dari LHR proyeksi PPJT & $90 \%$ \\
& \\
Social Discount Rate & $9 \%$ \\
Tingkat Inflasi Lampung & $3,53 \%$ \\
Rata-rata penumpang dalam 1 kendaraan & 3 \\
UMR Lampung 2020 & $\mathrm{Rp} 2.432 .001,57$ \\
Panjang Jalan Non Tol Bakauheni Terbanggi Besar & $224 \mathrm{~km}$ \\
& \\
\hline & $\quad$ Nilai Waktu \\
\hline Pendapatan per kapita (juta Rp/orang/tahun) & $\mathrm{Rp} 29.184 .018,84$ \\
Jumlah jam kerja per tahun (jam) & 2112 \\
Nilai waktu kerja orang per jam (Rp/orang/jam) & $\mathrm{Rp} 13.818,19$ \\
\hline Sumber: Analisis Penulis, 2020
\end{tabular}

Sumber: Analisis Penulis, 2020

Suatu proyek investasi pemerintah biasanya menimbulkan biaya dan menghasilkan manfaat di titik-titik waktu yang berbeda. Oleh sebab itu, untuk menentukan apakah proyek pemerintah memberikan manfaat bersih secara sosial atau tidak, seluruh biaya dan manfaat harus dievaluasi pada nilai saat ini (present value) dengan menggunakan tingkat diskonto sosial. Tingkat diskonto sosial adalah tingkat yang mencerminkan penilaian relatif dari masyarakat terhadap nilai kini dibandingkan dengan nilainya di masa depan. Ada variasi signifikan dalam kebijakan tingkat diskonto publik dalam praktik di seluruh dunia, dengan negara maju menerapkan tarif yang lebih rendah (3-7\%) dibandingkan negara berkembang yang disurvei (8-15\%) (Zhuang et al. 2007). Dalam penelitian ini menggunakan tingkat diskonto $9 \%$. 
Memilih tingkat diskonto sosial yang sesuai sangat penting bagi CBA, dan memiliki implikasi penting untuk alokasi sumber daya. Apabila tingkat diskonto ditetapkan terlalu tinggi, banyak proyek pemerintah yang memberikan manfaat bersih secara sosial dapat terhalangi pelaksanaannya, sedangkan apabila tingkat diskonto ditetapkan terlalu rendah dapat berisiko menimbulkan investasi yang tidak efisien secara ekonomi.

\section{Manfaat Penghematan Waktu}

Berdasarkan kondisi sebelum adanya jalan tol Bakauheni Terbanggi Terbanggi Besar dapat ditempuh dalam kisaran waktu 4 sampai dengan 5 tahun melalui jalan nasional yaitu Jalan Raya Lintas Timur Sumatera (sepanjang sekitar $224 \mathrm{~km}$ ). pada jalur tersebut terdapat beberapa area yang sering mengalami kepadatan lalu lintas yaitu jalan raya lintas timur sumatera pada wilayah Sidomulyo, Kalianda, Tarahan serta daerah sekitar persimpangan Jalan Raya Lintas Timur Sumatera dan Jalan Camping Raya dan Jalan HR M Mangundiprodjo. Namun dengan jalan tol Bakauheni - Terbanggi Besar, perjalanan dapat dipangkas dari 3 jam menjadi 2 jam. Dengan asumsi tersebut, manfaat waktu dapat dihitung seperti tabel berikut:

Tabel 7. Manfaat Waktu Jalan Tol Bakauheni Terbanggi Besar (Juta)

\begin{tabular}{lcccc}
\hline Tahun Konsesi & $\mathbf{5}$ & $\mathbf{1 0}$ & $\mathbf{2 0}$ & $\mathbf{4 0}$ \\
Manfaat & $\mathbf{2 0 2 0}$ & $\mathbf{2 0 2 5}$ & $\mathbf{2 0 3 5}$ & $\mathbf{2 0 5 5}$ \\
\hline Volume Traffic & 11340 & 15394 & 25324 & 68794 \\
Manfaat Penghematan Waktu & Rp 561.095 & Rp 761.683 & Rp 1.252 .992 & Rp 3.403.793 \\
\hline Sumber: Analisis Penulis, 2020 & & & &
\end{tabular}

\section{Manfaat Biaya Operasional Kendaraan}

Manfaat langsung yang dirasakan oleh masyarakat biasanya diambil dari selisih Biaya Operasi Kendaraan (BOK) sebelum dan sesudah adanya proyek. Nilai BOK diambil dari nilai BOK tahun 2019 (jalan mulai beroperasi). Nilai BOK bervariasi berdasarkan kecepatan kendaraan dan pada analisis ini nilai BOK yang dipakai adalah nilai BOK untuk mobil penumpang. Nilai BOK ditampilkan dalam tabel berikut:

\begin{tabular}{cc} 
Tabel 8. Nilai BOK tahun 2019 untuk mobil penu \\
\cline { 2 - 2 } $\begin{array}{c}\text { Kecepatan } \\
\text { (km/jam) }\end{array}$ & $\begin{array}{c}\text { BOK 2019 } \\
\text { (Rp/Kend/km) }\end{array}$ \\
\hline 10 & 7.364 \\
20 & 4.569 \\
30 & 3.546 \\
40 & 3.014 \\
50 & 2.717 \\
60 & 2.570 \\
70 & 2.534 \\
80 & 2.594 \\
90 & 2.737 \\
100 & 2.959 \\
\hline
\end{tabular}

Sumber: Kementerian PUPR, 2019 
Dengan asumsi kendaraan berjalan di jalan tol Bakauheni Terbanggi Besar $80 \mathrm{~km} / \mathrm{jam}$ sehingga BOK Rp. 2.594,- jarak $140 \mathrm{~km}$ dan apabila belum ada proyek jalan tol ini alternatifnya dengan melalui jalan nasional jarak $224 \mathrm{~km}$ dengan asumsi kecepatan $50 \mathrm{~km} / \mathrm{jam}$ sehingga BOK Rp. 2.717,-. Didapatkan perhitungan penghematan BOK sebagaimana tabel berikut:

Tabel 9. Manfaat BOK Jalan Bakauheni - Terbanggi Besar

\begin{tabular}{lcccc}
\hline Tahun Konsesi & $\mathbf{5}$ & $\mathbf{1 0}$ & $\mathbf{2 0}$ & $\mathbf{4 0}$ \\
Manfaat & $\mathbf{2 0 2 0}$ & $\mathbf{2 0 2 5}$ & $\mathbf{2 0 3 5}$ & $\mathbf{2 0 5 5}$ \\
\hline Volume Traffic & 11340 & 15394 & 25324 & 68794 \\
Manfaat BOK & $\mathrm{Rp} 1.107 .395$ & $\mathrm{Rp} 1.503 .281$ & $\mathrm{Rp} 2.472 .943$ & $\mathrm{Rp} 6.717 .828$ \\
\hline
\end{tabular}

Sumber: Analisis Penulis, 2020

\section{Hasil Perhitungan Cost Benefit Analysis (CBA)}

Hasil CBA dalam mengevaluasi Proyek jalan tol Bakauheni - Terbanggi Besar ditunjukkan dalam juta rupiah dalam tabel di bawah ini. Manfaat berasal dari manfaat langsung sebagai cerminan dari aktivitas ekonomi masyarakat yang terkait penghematan waktu dan penghematan BOK yang diperoleh dari adanya jalan tol bakauheni Terbanggi Besar. Ini mewakili nilai yang dipersepsikan oleh masyarakat ketika menggunakan Jalan Tol Bakauheni Terbanggi Besar akibat perubahan pada biaya dan waktu yang dihabiskan dibandingkan melalui jalan nasional sebagai alternated sebelum adanya proyek jalan tol.

Tabel 10. Hasil Perhitungan Biaya dan Manfaat Jalan Tol Bakaeuheni Terbanggi Besar

\begin{tabular}{|c|c|c|c|}
\hline \multicolumn{4}{|c|}{ Analisis Biaya Manfaat Sosial (Nilai Kotor selama 40 tahun) } \\
\hline Total Biaya & Rp. Juta & & $27.934 .605,0$ \\
\hline Biaya Investasi & Rp. Juta & & $12.630 .236,4$ \\
\hline Biaya Operasional & Rp. Juta & & $15.140 .184,31$ \\
\hline Biaya Alih Fungsi Lahan & Rp. Juta & & $10.856,22$ \\
\hline Biaya Polusi & Rp. Juta & & $153.328,09$ \\
\hline Total Manfaat ekonomi & Rp. Juta & & 31.428 .086 \\
\hline Manfaat Penghematan Waktu & Rp. Juta & & 10.568 .928 \\
\hline Manfaat BOK & Rp. Juta & & 20.859 .158 \\
\hline \multicolumn{4}{|c|}{ Nilai Terdiskonto selama 40 tahun, SDR 9\% } \\
\hline NPV Ekonomi & Rp. Juta & 3.542 .896 & \\
\hline Rasio Biaya Manfaat & & 1,13 & \\
\hline EIRR & $\%$ & $10,13 \%$ & \\
\hline
\end{tabular}

Sumber: Analisis Penulis, 2020

Total nilai saat ini dari manfaat Proyek adalah Rp 31,4 triliun. Jumlah ini lebih besar daripada biaya saat ini sebesar Rp 27,8 Triliun, sehingga Proyek memberikan nilai ekonomi bersih saat ini (ENPV) sebesar Rp 3,6 Triliun. Karena manfaatnya lebih tinggi daripada biaya, hal ini mencerminkan manfaat bersih Proyek bagi masyarakat dengan Rasio Biaya-Manfaat (Benefit-Cost Ratio/BCR) sebesar 1,13x. BCR digunakan untuk membandingkan total manfaat terdiskonto terhadap total biaya terdiskonto. Oleh sebab itu, rasio biaya-manfaat sebesar $1,13 \mathrm{x}$ berarti bahwa manfaat yang dihasilkan melebihi biaya yang ditimbulkan, sehingga pilihan pembangunan jalan tol Bakauheni Terbanggi Besar layak dibangun. EIRR Proyek adalah sebesar 10,14\%, yang melebihi tingkat diskonto sosial yang sebesar $9 \%$. Model CBA menunjukkan nilai ekonomi bersih saat ini (ENPV) yang positif dan EIRR yang 
lebih besar daripada biaya peluang sosial dari modal, yang mengindikasikan bahwa Proyek akan memberikan manfaat bersih yang positif bagi perekonomian.

Namun, dilihat dari hasil BCR tersebut, rasio biaya manfaat mendekati 1, sehingga manfaat dari hasil aktivitas ekonomi yang ditunjukkan dari nilai manfaat CBA tersebut perlu ditingkatkan. Peningkatan pengembangan wilayah daerah sekitar jalan tol akan menghasilkan lebih banyak nilai manfaat baik bagi peningkatan lalu lintas harian yang pada akhirnya membangkitkan perekonomian wilayah Lampung.

\section{KESIMPULAN}

Berdasarkan analisis yang dilakukan berdasarkan proyeksi proyek setelah beroperasi, kesimpulan yang didapat adalah sebagai berikut:

a. Manfaat ekonomi yang dapat diperoleh dari pembangunan proyek jalan tol trans Sumatera ruas bakauheni Terbanggi Besar dinilai dengan nilai sekarang sebesar $\mathrm{Rp} 31,18$ Triliun

b. Total biaya yang diperlukan untuk pembangunan proyek jalan tol trans sumatera serta pengelolaan dan pemeliharaannya serta biaya eksternalitas pada nilai sekarang sebesar Rp. 27,93 triliun

c. Nilai Benefit Cost Ratio (BCR) yang dihasilkan adalah 1,13, yang berarti proyek pembangunan jalan tol trans sumatera ruas bakauheni Terbanggi Besar memenuhi kelayakan jika dilihat dari biaya yang dibutuhkan dengan manfaat yang didapat secara ekonomi

\section{REKOMENDASI}

1. Perlunya pembuatan analisis Biaya Manfaat sebelum dilakukannya pembangunan proyek sebagai pemilihan prioritas proyek yang akan dibangun.

2. Analisis Biaya Manfaat disusun secara lengkap dan rinci, identifikasi biaya dan manfaat dilakukan tidak hanya melalui biaya langsung namun juga biaya tak langsung.

3. Perlunya langah-langkah lebih lanjut dari Pemerintah apabila kelayakan ekonomi proyek pemerintah marginal sehingga proyek pembangunan bisa lebih bermanfaat secara ekonomi.

\section{DAFTAR PUSTAKA}

Diez, Tomas Herrero. (2015). PPP on Toll Road in Indonesia.

Flyvbjerg, Bent, Mette Skamris Holm, and Soren Buhl. (2002). Underestimating Costs in Public Works Projects: Error or Lie?. Journal of the American Planning Association 68(3):279-95.

Handayani, Siti Asih, Effendi Irwan, and Viantimala Begem. (2017). Produksi Dan Pendapatan Usahatani Padi Di Desa Pujo Asri Kecamatan Trimurjo Kabupaten Lampung Tengah. Jiia 5(4):422-29.

Hidayat, Aceng, Nuva Nuva, and Sylviana Dewi Syafitri. (2017). Estimasi Nilai Pajak Emisi Dan Kebijakan Kendaraan Umum Berbahan Bakar Bensin Di Kota Bogor. RISALAH KEBIJAKAN PERTANIAN DAN LINGKUNGAN: Rumusan Kajian Strategis Bidang Pertanian Dan Lingkungan 3(1):1.

Matanhire, Batsirai Brian. (2019). Cost Benefit Analysis of a Regional Arterial PPP Toll Road Project : A Case Study of the Proposed R-1 Toll Road.

Menteri Lingkungan Hidup. (2014). Berita Negara. Menteri Lingkungan Hidup Peraturan 
Menteri Kesehatan Republik Indonesia (879):2004-6.

Moleong, Lexy J. (2006). Metodologi Penelitian Kualitatif. Bandung: Remaja Rosdakarya.

Kementerian Pekerjaan Umum dan Perumahan Rakyat. (2017). Pemahaman Umum Studi Kelayakan.

Badan Pusat Statistik. (2019). Output Tabel Dinamis P. 71 in Data PDRB Provinsi di Indonesia.

Zhuang, Juzhong, Zhihong Liang, Tun Lin, and Franklin De Guzman. (2007). Theory and Practice in the Choice of Social Discount Rate for Cost-Benefit Analysis: A Survey. ERD Working Paper Series (94):1-45. 